\title{
Jolanta Korkosz-Gębska
}

Politechnika Warszawska

e-mail: j.korkosz@wip.pw.edu.pl

\section{REKLAMA A KONCEPCJA SPOŁECZNEJ ODPOWIEDZIALNOŚCI PRZEDSIĘBIORSTW Z BRANŻY FARMACEUTYCZNEJ}

\section{ADVERTISEMENT VS. CONCEPT OF CORPORATE SOCIAL RESPONSIBILITY IN COMPANIES OF PHARMACEUTICAL INDUSTRY}

DOI: $10.15611 /$ pn.2017.478.24

JEL Classification: M14

Streszczenie: W artykule przedstawiono wybrane aspekty społecznej odpowiedzialności przedsiębiorstw farmaceutycznych, która w związku ze specyfiką branży powinna stać się ich nadrzędną wartością. Celem pracy była identyfikacja rozbieżności między oczekiwanym wobec firm farmaceutycznych podejściem do realizacji założeń koncepcji społecznej odpowiedzialności biznesu a nieuczciwymi praktykami w obszarze zagadnień konsumenckich. Przeprowadzona analiza opisowa, studia literaturowe oraz obserwacja potwierdziły istnienie dysonansu pomiędzy deklarowaną troską o dobro ludzi a nieetycznymi działaniami w zakresie promocji oferowanych produktów, jak również wskazały na konieczność implementacji założeń koncepcji CSR we wszystkich obszarach funkcjonowania przedsiębiorstw z branży farmaceutycznej.

Słowa kluczowe: społeczna odpowiedzialność przedsiębiorstw, reklama, etyka, branża farmaceutyczna.

Summary: The article presents examples of unethical advertising in opposition to declared implementation of Corporate Social Responsibility of pharmaceutical companies. The aim of the work was to identify the discrepancy between CSR concept in the pharmaceutical industry and unethical aspects in the promotion of the offered products. Descriptive analysis, literature studies and observation have confirmed the existence of discrepancies between the declared concern for the welfare of people and unfair practices in the promotion of the offered products, and pointed to the need to implement CSR concepts in all aspects of the pharmaceutical business.

Keywords: Corporate Social Responsibility, advertisement, ethics, pharmaceutical industry. 
Jolanta Korkosz-Gębska

Konsumenci to żywi ludzie. Ich życie nie polega na samym kupowaniu.

Marc Gobe

\section{Wstęp}

Implementacja założeń koncepcji społecznej odpowiedzialności przedsiębiorstw (Corporate Social Responsibility, CSR) stała się w ostatnich latach trendem w zarządzaniu, choć dla wielu firm jest wyłącznie modą marketingową. Prowadzi to do pewnego rodzaju anomalii: firmy, których działalność wiąże się z dużą uciążliwością dla środowiska naturalnego, realizują symboliczne inicjatywy, dzięki którym stają się przykładami dobrych praktyk w zakresie wdrożenia koncepcji CSR, podczas gdy firmy mające bardzo często istotny wpływ na zdrowie i życie wielu ludzi, pozostają z reguły obojętne na tego typu działania.

Branża farmaceutyczna należy do najszybciej rozwijających się i najbardziej innowacyjnych sektorów produkcyjnych. Specyfika oferowanych produktów wpływających na zdrowie, a nawet życie ludzi sprawia, że przedsiębiorstwa funkcjonujące $\mathrm{w}$ tej branży podlegają restrykcyjnym przepisom, związanym m.in. z bezpieczeństwem leków czy sposobem prezentowania informacji o preparatach medycznych. Mimo rosnącej liczby firm realizujących działania z zakresu społecznej odpowiedzialności przedsiębiorstw można stwierdzić, iż aktywność w tym obszarze przedstawicieli branży farmaceutycznej jest nadal niewystarczająca. Jest to szczególnie widoczne w kampaniach reklamowych, które bardzo często nie są dostosowane do prawnych obostrzeń w zakresie promocji produktów leczniczych. Istnieje wiele przykładów nieprzestrzegania zapisów ustawy Prawo farmaceutyczne. W niniejszej pracy zostaną one zestawione z ideą społecznej odpowiedzialności przedsiębiorstw, która ze względu na specyfikę branży farmaceutycznej powinna być jej „naturalną” cechą.

Celem pracy była identyfikacja rozbieżności między deklarowaną realizacją założeń koncepcji społecznej odpowiedzialności biznesu a nieuczciwymi praktykami w zakresie promocji produktów farmaceutycznych. Przeprowadzona analiza opisowa, studia literaturowe oraz obserwacja potwierdziły istnienie pewnego rodzaju dysonansu między oczekiwanym wobec firm farmaceutycznych podejściem do koncepcji CSR a nieuczciwymi praktykami w zakresie zagadnień konsumenckich.

Przytoczone przykłady wykorzystano jedynie w celach naukowych, tj. analizy relacji między deklarowaną społeczną odpowiedzialnością przedsiębiorstw farmaceutycznych a stosowanymi przez nie praktykami w zakresie reklamy oferowanych produktów i nie należy traktować ich jako próby dyskredytacji działalności przedsiębiorstw, których dotyczą. 


\section{Społeczna odpowiedzialność przedsiębiorstw farmaceutycznych}

Wobec przedsiębiorstw z branży farmaceutycznej, działających w obszarze ochrony zdrowia, oczekiwania w zakresie implementacji założeń koncepcji CSR są wyższe niż w przypadku innych sektorów. „Misją krajowego przemysłu farmaceutycznego jest zapewnienie pacjentom skutecznych i bezpiecznych leków. Istotnym elementem tej misji jest także stała dbałość o konkurencyjne ceny produktów, wpływająca na optymalizację publicznych nakładów na farmakoterapię" [Instytut Badań nad Gospodarką Rynkową 2013]. W kontekście chorób cywilizacyjnych i starzejącego się społeczeństwa skuteczność i bezpieczeństwo leków nabierają szczególnego znaczenia.

\subsection{Teoretyczne aspekty społecznej odpowiedzialności przedsiębiorstw}

Kwestie związane z etyką biznesu można odnaleźć w pismach starożytnych filozofów i przywódców religijnych, jednak pierwsze naukowe opracowania poświęcone koncepcji CSR pojawiły się u schyłku XIX w. Klasyczna definicja społecznej odpowiedzialności przedsiębiorstw przedstawiona w książce Ewangelia bogactwa opiera się na dwóch podstawach: zasadzie miłosierdzia (dobroczynności) oraz włodarstwa (powiernictwa) [Stoner i in. 1999].

Za „ojca” społecznej odpowiedzialności biznesu uznaje się jednak H.R. Bowena, który w opracowanej w 1953 r. książce Social Responsibilities of the Businessmen po raz pierwszy zdefiniował pojęcie społecznej odpowiedzialności jako „obowiązek prowadzenia polityki, podejmowania decyzji oraz realizowania działań, które są zbieżne z oczekiwaniami społecznymi” [Bowen 1953]. Zdaniem M. Friedmana „istnieje tylko jeden jedyny rodzaj społecznej odpowiedzialności ze strony świata biznesu - wykorzystywać swe zasoby i podejmować działalność w celu zwiększenia własnych zysków na tyle, na ile pozostaje to zgodne z regułami gry. Innymi słowy - angażować się w otwartą i wolną konkurencję, bez podstępów i oszustw” [Friedman 1993]. Według P. Druckera „każda organizacja gospodarcza ponosi pełną odpowiedzialność za swój wpływ na społeczność lokalną i społeczeństwa, w których działa” [Drucker 1999]. „Odpowiedzialność” można interpretować w dwóch przeciwstawnych kierunkach: jako odpowiedzialność negatywną (restrykcyjną), związaną z przeszłością, będącą formą rozliczenia za popełnione czyny oraz odpowiedzialność pozytywną, dotyczącą przyszłości, będącą formą brania odpowiedzialności za pewne dobro [Filek 2002].

Zgodnie z normą PN-ISO 26000:2012 (Wytyczne dotyczące społecznej odpowiedzialności), ,zasadniczą cechą CSR jest gotowość organizacji do uwzględniania, podczas podejmowania decyzji, kwestii społecznych i środowiskowych oraz rozliczania się z wpływu podejmowanych decyzji i działań na społeczeństwo i środowisko. Oznacza to postępowanie zarówno przejrzyste, jak i etyczne, przyczyniające się do zrównoważonego rozwoju, zgodnie z obowiązującym prawem oraz spójne z mię- 
dzynarodowymi normami postępowania. Oznacza to również, że społeczna odpowiedzialność jest uwzględniana we wszystkich działaniach organizacji, praktykowana w jej kontaktach oraz bierze pod uwagę interesy interesariuszy" [PKN 2012]. W normie PN-ISO 26000:2012 zidentyfikowano 7 kluczowych obszarów, do których należą: ład organizacyjny, prawa człowieka, praktyki z zakresu pracy, środowisko, uczciwe praktyki operacyjne, zagadnienia konsumenckie, zaangażowanie społeczne i rozwój społeczności lokalnej.

Zainteresowanie implementacją założeń koncepcji CSR wzrasta, jednak dla wielu organizacji stanowi jedynie skuteczne narzędzie budowania lub wzmocnienia pozytywnego wizerunku, a nie element długofalowej polityki firmy, determinującej zrównoważony rozwój przedsiębiorstwa.

\subsection{Społeczna odpowiedzialność w branży farmaceutycznej}

Przedsiębiorstwa z branży farmaceutycznej wykazują się umiarkowanym zainteresowaniem wdrożeniem koncepcji CSR. Do liderów w tym obszarze należą: Grupa Adamed, Grupa Sanofi, GlaxoSmithKline oraz Polpharma. Do raportu „Odpowiedzialny biznes w Polsce 2015. Dobre praktyki" swoją aktywność w zakresie CSR zgłosiło tylko 6 firm z branży farmaceutycznej, opisując łącznie 31 praktyk (na 530 wszystkich zgłoszonych do publikacji) [Forum Odpowiedzialnego Biznesu 2016]. Aktywność firmy Polpharma dotyczyła głównie praktyk z zakresu pracy oraz zaangażowania społecznego i rozwoju społeczności lokalnej. Ważnym krokiem w tym obszarze było także stworzenie i wdrożenie Strategii CSR Grupy Polpharma, w której uczestniczyli interesariusze zewnętrzni oraz przedstawiciele najważniejszych obszarów biznesowych w firmie [Forum Odpowiedzialnego Biznesu 2016].

Zasady prowadzenia biznesu w sposób przejrzysty i uczciwy przy jednoczesnym zapewnieniu bezpiecznych i higienicznych warunków pracy, poszanowaniu praw człowieka, odpowiedzialności za jakość produktu oraz za środowisko zostały opisane w Kodeksie Postępowania Dostawców Grupy Polpharma.

W grudniu 2016 r. Polpharma przystąpiła do inicjatywy United Nations Global Compact, zobowiązując się tym samym do przestrzegania i popularyzacji 10 zasad UN Global Compact oraz regularnego raportowania postępów w tym obszarze [Polpharma 2016]. Firma podpisała także „Deklarację polskiego biznesu na rzecz zrównoważonego rozwoju” i jest sygnatariuszem Karty Różnorodności.

\section{Etyczne aspekty reklamy produktów leczniczych}

Współczesny marketing koncentruje się na realizacji celów ekonomicznych przy równoczesnym przestrzeganiu długofalowych potrzeb konsumentów oraz potrzeb społecznych [Pazio 2013]. Reklama jest podstawową formą komunikowania się przedsiębiorstwa z rynkiem [Altkorn (red.) 1992] i ma za zadanie m.in. zwracać uwagę poprzez swoje cechy fizyczne, tj. przekaz reklamowy [Pazio 2015]. 
Producenci, agencje reklamowe oraz media zobowiązane są do przestrzegania Kodeksu Etyki Reklamy (KER), opracowanego przez Radę Reklamy. W art. 3 reklamę zdefiniowano jako ,przekaz zawierający w szczególności informację lub wypowiedź, zwłaszcza odpłatny lub za wynagrodzeniem w innej formie, towarzyszący czyjejkolwiek działalności, mający na celu zwiększenie zbytu produktów, inną formę korzystania z nich lub osiągnięcie innego efektu, które są pożądane przez reklamodawcę. Do reklamy zalicza się również promocję sprzedaży, oferty kierowane do odbiorców za pomocą marketingu bezpośredniego lub sponsoring" [Rada Reklamy 2014]. Najpotężniejsze medium reklamowe stanowi reklama telewizyjna, umożliwiająca dotarcie do szerokiego spektrum konsumentów przy niskim koszcie jednostkowym ekspozycji [Kotler, Keller 2012].

\subsection{Reklama produktów leczniczych i suplementów diety}

„Reklamą produktu leczniczego jest działalność polegająca na informowaniu lub zachęcaniu do stosowania produktu leczniczego, mająca na celu zwiększenie: liczby przepisywanych recept, dostarczania, sprzedaży lub konsumpcji produktów leczniczych" [Ustawa z 6 września 2001]. Reklama produktów leczniczych nie może:

- wprowadzać w błąd,

- polegać na oferowaniu lub obiecywaniu jakichkolwiek korzyści w zamian za nabycie produktu,

- być kierowana do dzieci [Ustawa z 6 września 2001].

Mimo jasnych wytycznych związanych z promowaniem produktów leczniczych niektóre przedsiębiorstwa z branży farmaceutycznej nie przestrzegają ustalonych zasad reklamowania swoich produktów. Problem stanowi również promocja suplementów diety, czyli środków spożywczych podawanych w celu uzupełnienia niedoborów w diecie [Ustawa z 25 sierpnia 2006], reklamowanych bardzo często jako produkty o właściwościach leczniczych. Podobnie jak w przypadku produktów leczniczych, reklama suplementów diety również wiąże się z pewnymi ograniczeniami, nie może bowiem „wprowadzać w błąd, w szczególności co do charakteru suplementu, w tym jego nazwy, rodzaju, właściwości, składu, ilości, trwałości, źródła lub miejsca pochodzenia, metod wytwarzania lub produkcji oraz przez przypisywanie środkowi spożywczemu działania lub właściwości, których nie posiada, a także przez sugerowanie, że środek spożywczy posiada specjalne właściwości, jeżeli wszystkie podobne środki spożywcze posiadają takie właściwości, nie może przypisywać suplementowi diety właściwości zapobiegania chorobom lub ich leczenia ani odwoływać się do takich właściwości" [Ustawa z 25 sierpnia 2006]. 


\subsection{Przyklady naruszeń $w$ zakresie reklamowania produktów leczniczych i suplementów diety}

Prezentację zidentyfikowanych naruszeń w zakresie reklamowania produktów leczniczych i suplementów diety warto rozpocząć od komunikatu, który w okresie prac nad niniejszym artykułem pojawiał się bardzo często w 4 rozgłośniach radiowych i dotyczył reklamy radiowej suplementu diety Chela Mag B6. Zgodnie z Decyzją Prezesa Urzędu Ochrony Konkurencji i Konsumentów (UOKiK): sformułowania „najczęściej polecanym przez farmaceutów magnezem na rynku” i „najczęściej polecanym przez farmaceutów preparatem magnezowym w Polsce" zostały uznane za bezpodstawne [UOKiK 2017]. Kolejny zarzut dotyczył tego, że reklama powołuje się na autorytet zawodowy farmaceuty, a poprzez rozpowszechnianie nieprawdziwych informacji na stronie internetowej (,Farmaceuci uznali produkt za najbardziej godny poleceniu pacjentom") należy ją uznać za nieuczciwą praktykę rynkową, mogącą wprowadzić niektórych konsumentów w błąd. Decyzją Prezesa UOKiK, w związku z naruszeniem zbiorowych interesów konsumentów, producent suplementu diety został zobowiązany m.in. do sprostowania poprzez „wyemitowanie przez okres 2 tygodni w godzinach od 10:00 do 18:00 w następujących rozgłośniach radiowych: RMF FM, Radio ZET, Program I Polskiego Radia, Program III Polskiego Radia, co najmniej 80 razy w każdej stacji, komunikatu radiowego, o czasie emisji nie krótszym niż 30 sekund" [UOKiK 2017].

$\mathrm{W}$ roku 2011 UOKiK zakwestionował informacje przekazywane w trakcie radiowo-telewizyjnej kampanii produktów NeoMag Cardio i NeoMag Forte za pośrednictwem aktorów, powołujących się na tytuły naukowe, których w rzeczywistości nie miały. Za wprowadzenie w błąd konsumentów UOKiK nałożył na producenta karę w wysokości 80,6 tys. zł [Press 2011].

Komisja Etyki Reklamy uznała, iż spot radiowy preparatu Hydronea zachęca do niebezpiecznych zachowań, jakimi są lekceważenie lub bagatelizowanie wymiotów u dzieci. Opinia dotyczyła treści reklamy, w której lekarka telefonicznie radzi matce, aby podała swojemu wymiotującemu dziecku suplement diety Hydronea, co zapobiegnie jego odwodnieniu [Forum Farmaceutyczne 2015]. W ocenie KER reklama zachęcała do niebezpiecznych zachowań, a tym samym nadużywała zaufania odbiorców, wykorzystując ich brak doświadczenia lub wiedzy [Forum Farmaceutyczne 2015].

W marcu 2015 r. GIF nakazał natychmiastowe zaprzestanie emitowania reklamy tabletek Neosine oraz sprostowanie prezentowanych wcześniej treści w trzech stacjach telewizyjnych [Magazyn Aptekarski 2016]. Przyczyną takiej decyzji był tekst, z którego wynikało, że zastosowanie leku w ciągu 48 godzin od zainfekowania uchroni przed grypą lub przeziębieniem [Magazyn Aptekarski 2016]. Zdaniem GIF doszło do złamania przepisów ustawy Prawo farmaceutyczne, tj. art. 53 (produkt leczniczy nie może wprowadzać w błąd), art. 56 (zakaz reklamowania produktu 
leczniczego zawierającego informacje niezgodne z zatwierdzoną „Charakterystyką produktu leczniczego") i art. 55 (reklama kierowana do wiadomości publicznej nie może zapewniać, że przyjmowanie leku gwarantuje właściwy skutek) [Magazyn Aptekarski 2016].

Wątpliwości natury etycznej budzi także reklama lizaków i sprayu Natur-Sept, w którą zaangażowany jest lekarz niewykonujący zawodu i nieposiadający specjalizacji w żadnej dziedzinie medycyny [Magazyn Aptekarski 2016]. Ze względu na brak przynależności do jakiejkolwiek izby nie podlega tym samym jurysdykcji rzecznika odpowiedzialności zawodowej czy sądu koleżeńskiego [Magazyn Aptekarski 2016].

UOKiK wszczął również postępowanie w sprawie reklamy żelków Magmisie, w której pojawiają się stwierdzenia, iż dzieci, które je stosują, lepiej radzą sobie ze stresem i potrafią się skoncentrować [Wolters Kluwer 2017]. Autorytet pedagoga szkolnego, który zaleca stosowanie tego suplementu, ma uwiarygodnić przekaz, mimo iż w kompetencjach zawodowych pedagoga szkolnego nie mieści się doradztwo w zakresie wiedzy medycznej/farmaceutycznej.

UOKiK prowadzi wszczęte w 2016 r. postępowania z zarzutami związanymi z reklamą produktów: RenoPuren Zatoki Hot oraz RenoPuren Zatoki Junior [UOKiK 2016]. Główne zarzuty dotyczą sugerowania i stwarzania wrażenia, że produkty posiadają właściwości lecznicze, przypisywania środkowi spożywczemu działania i właściwości, których on nie posiada, jak również właściwości zapobiegania chorobom oraz leczenia chorób ludzi [UOKiK 2016]. Podobne zastrzeżenia dotyczą suplementów diety o nazwie Pneumolan oraz Pneumolan Plus [UOKiK 2016].

Z kolei w reklamie produktu leczniczego Sudafed (,Zablokowany nos i zatoki? Ociężała głowa? - Tak. To stan przeziębionej głowy") Główny Inspektor Farmaceutyczny stwierdził naruszenie art. 53 ustawy Prawo farmaceutyczne (reklama nie może wprowadzać w błąd, powinna prezentować produkt leczniczy obiektywnie oraz informować o racjonalnym stosowaniu) oraz art. 56 pkt. 2 ustawy, zabraniającego prowadzenia reklamy produktu leczniczego zawierającej informacje niezgodne z zatwierdzoną „Charakterystyką produktu leczniczego” [GIF 2015].

GIF nakazał także zaprzestać prowadzenia reklamy wizualnej leków, uznanej za niezgodną z obowiązującymi przepisami, w darmowej wersji programu „Gabinet Dr Widget", służącego do zarządzania przychodnią lub gabinetem lekarskim. Umieszczanie reklam produktów leczniczych w bezpłatnym programie komputerowym uznane zostało za równoznaczne z przekazywaniem korzyści materialnej osobom uprawnionym do wystawiania recept [Rzeczpospolita 2016].

Ostatni przykład naruszeń w analizowanym obszarze nie dotyczy firmy farmaceutycznej, jednak wiąże się z reklamą produktu leczniczego. W roku 2011 GIF nakazał Spółce Komandytowej „Teatr Kamienica” Fundacja Wspierania Twórczych Inicjatyw Teatralnych ATUT i S-ka „zaprzestanie prowadzenia niezgodnej z obowiązującymi przepisami reklamy produktu leczniczego Acard, kierowanej do publicz- 
nej wiadomości, polegającej na zamieszczeniu w scenariuszu spektaklu sztuki „I tak Cię kocham" sformułowania: A na serce Akard (Acard) niech pamięta [GIF 2011]. Według GIF naruszenie dotyczyło art. 60 Ustawy prawo farmaceutyczne (reklama produktu leczniczego może być prowadzona jedynie przez podmiot odpowiedzialny lub na jego zlecenie), par. 6 Rozporządzenia Ministra Zdrowia w sprawie reklamy produktów leczniczych (brak szczegółowych informacji o produkcie). Przekaz reklamowy dodatkowo wzmacniał fakt, iż producent leku był mecenasem spektaklu [GIF 2011].

\section{Zakończenie}

W związku ze specyfiką branży farmaceutycznej firmy działające w tym sektorze powinny dostarczać niekończących się przykładów dobrych praktyk we wszystkich obszarach zdefiniowanych w normie PN-ISO 26000:2012. Tymczasem na polskim rynku niewielka liczba firm farmaceutycznych zainteresowana jest implementacją założeń koncepcji CSR. Realizowane praktyki dotyczą z reguły tylko pewnych obszarów normy, co w wielu przypadkach pozwala na promowanie przedsiębiorstwa, przy jednoczesnym niespełnieniu wymagań związanych z jej pozostałymi obszarami, jak np. opisanymi zagadnieniami konsumenckimi. Poprawy niewątpliwie wymaga promocja produktów leczniczych, jak również suplementów diety, wpisująca się w niemal wszystkie obszary normy. Firmy posiadające jasno określoną politykę w zakresie społecznej odpowiedzialności są w stanie funkcjonować na rynku bez opierania swojej działalności na nieuczciwych praktykach, związanych z reklamą produktów leczniczych i suplementów diety.

„Kłopotliwe” problemy z promocją może także zmienić Kodeks Dobrych Praktyk Reklamy Suplementów Diety, opracowany przez cztery branżowe organizacje zrzeszające producentów i dystrybutorów suplementów diety (KRSiO - Krajową Radę Suplementów i Odżywek, PASMI - Polski Związek Producentów Leków Bez Recepty, Związek Producentów i Dystrybutorów SUPLEMENTY POLSKA oraz POLFARMED - Polską Izbę Przemysłu Farmaceutycznego i Wyrobów Medycznych). Celem kodeksu jest ,propagowanie norm etycznych i dobrych obyczajów wśród reklamodawców oraz wprowadzenie wysokich standardów w zakresie promocji suplementów diety" [Farmacja Praktyczna 2017]. Wdrożenie kodeksu może doprowadzić do zmian w przekazie reklamowym, poprawić jego przejrzystość i czytelność oraz sprawić, że reklamy suplementów będą bardziej rzetelne i łatwiejsze w identyfikacji przez konsumentów [Farmacja Praktyczna 2017]. Uporządkowanie kwestii związanych z promocją oferowanych produktów może być jednym z pierwszych kroków w zakresie planowania i realizacji strategii CSR przedsiębiorstw farmaceutycznych. 


\section{Literatura}

Altkorn J. (red.), Podstawy marketingu, Instytut Marketingu, Kraków, s. 326.

Bowen H.R., 1953, Social Responsibiliteies of the Businessman, Harper \& Row, New York, s. 115.

Drucker P.F., 1999, Spoteczeństwo kapitalistyczne, PWN, Warszawa, s. 87.

Farmacja Praktyczna, 2017, Kodeks Dobrych Praktyk Reklamy Suplementów Diety, http://www.farmacjapraktyczna.pl (26.03.2017).

Filek J., 2002, O wolności i odpowiedzialności podmiotu gospodarującego, Akademia Ekonomiczna w Krakowie, Kraków, s. 160.

Forum Farmaceutyczne, 2015, Nieetyczna reklama firmy farmaceutycznej Aflofarm Farmacja, http://forumfarmaceutyczne.blog.pl (26.03.2017).

Forum Odpowiedzialnego Biznesu, 2016, CSR $w$ farmacji wciąż zostawia duże pole do popisu, http://odpowiedzialnybiznes.pl (26.03.2017).

Friedman M., 1993, Kapitalizm i wolność, tłum. Lasota M., Kondratowicz A., Centrum im. Adama Smitha \& Rzeczpospolita, Warszawa, s. 127-128.

GIF, 2014, Główny Inspektor Farmaceutyczny, Decyzja GIF-P-R-450/75-4/JD/14, Warszawa.

GIF, 2011, Główny Inspektor Farmaceutyczny, Decyzja GIF-P-R-450/106-4/JD/10/11, Warszawa.

Instytut Badań nad Gospodarką Rynkową, 2013, Strategia rozwoju krajowego przemystu farmaceutycznego do roku 2030, Warszawa, s. 10.

Kotler P., Keller K.L., 2012, Marketing, Dom Wydawniczy REBIS Sp. z o.o., Poznań, s. 543.

Magazyn Aptekarski, 2016, Reklamacja w sprawie reklam, nr 144/maj, s. 16.

Pazio N.M., 2013, Marketing. Teoria pragmatyczna, Oficyna Wydawnicza Politechniki Warszawskiej, Warszawa, s. 414-415.

Pazio N.M., 2015, Marketing Q lojalności, Difin, Warszawa, s. 122.

Polpharma, 2016, Inicjatywa United Nations Global Compact, http://www.polpharma.pl (26.03.2017).

PKN, 2012, Polski Komitet Normalizacyjny, PN-ISO 26000:2012, Wytyczne dotyczace społecznej odpowiedzialności, Warszawa, s. 18, 22-26, 33-34.

Press, 2011, One-2-One, E. Wedel i Aflofarm ukarane przez UOKiK za nieuczciwe promocje, http://www.press.pl (26.03.2017).

Puls Farmacji, 2017, Sektor farmaceutyczny stawia na reklamę, http://pulsfarmacji.pl (26.03.2017).

Rada Reklamy, 2014, Kodeks Etyki Reklamy, https://www.radareklamy.pl (26.03.2017).

Rzeczpospolita, 2016, Darmowy program z reklama leków to przekazywanie lekarzom korzyści, http://www.rp.pl (26.03.2017).

Stoner J.A.F., Freeman R.E., Gilbert D.R.,1999, Kierowanie, PWE, Warszawa, s. 112.

Ustawa z 6 września 2001 Prawo farmaceutyczne, Dz.U., nr 126, poz. 1381 ze zm.

Ustawa z 25 sierpnia 2006 o bezpieczeństwie żywności i żywienia, Dz.U. 06.171.1225.

UOKiK, 2016, Postępowania Prezesa UOKiK w sprawie praktyk naruszających zbiorowe interesy konsumentów dotyczace reklam suplementów diet, https://www.uokik.gov.pl (26.03.2017).

Wolters Kluwer, 2017, UOKiK: wykorzystanie autorytetu pedagoga do reklamy suplementów jest nieetyczne, http://www.oswiata.abc.com.pl (26.03.2017). 